\title{
Seasonal Effects on Starch Contents Evaluated in Cassava Roots
}

\author{
Genilso Gomes de Proença ${ }^{1}$, Carla Adriana Pizarro Schmidt ${ }^{1} \&$ José Airton Azevedo dos Santos ${ }^{1}$ \\ ${ }^{1}$ Universidade Tecnológica Federal do Paraná, Medianeira, PR, Brazil \\ Correspondence: Carla Adriana Pizarro Schmidt, Av. Brasil, 4232. CEP 85884-000. Medianeira, PR, Brazil. Tel: \\ 55-(45)-3240-8000. E-mail: carlaschmidt@utfpr.edu.br
}

Received: August 2, 2017

doi:10.5539/jas.v9n10p244
Accepted: September 3, $2017 \quad$ Online Published: September 15, 2017

URL: https://doi.org/10.5539/jas.v9n10p244

\begin{abstract}
Starches have a wide range of uses and their consumption has increased over the years, resulting in a growth in the agro-industries that produce them. Cassava is a very important plant for agri-business and one of the main products obtained from its roots is starch. Although cassava can be harvested throughout the year, its quality varies greatly through the seasons; this is because it is influenced by soil and climatic factors, as well as the genetic characteristics of the species. These influences result in seasonal oscillations in root classification based on the starch content available at the time of product delivery. Faced with this problem, the objective of this study was the collection and evaluation of documentary data for 3 years of product quality samples. This was done in order to observe the situation and propose tools that can minimize problems resulting from the quality of raw material received by starch producers throughout the year. It was observed that in the winter period there was an increase in root starch content, despite the differences between the months not being statistically significantly, they are financially representative of this agro-industry sector. At the end of the study, a proposal for a methodology for calculating payment per gram of starch is presented in order to minimize the problem.
\end{abstract}

Keywords: agronomy, food industry, Manihot esculenta, production planning, seasonality

\section{Introduction}

Rosenthal et al. (2012) proposed that cassava is the second most important root, behind only the English potato. This is due to it being an important feedstock and its use in the production of starch and fuel, among other applications. It is considered the fifth most important crop in terms of calorie provision by food, and is especially important to residents of sub-Saharan Africa.

When considering the use of cassava as a raw material for various industries and the predicted population growth, it is expected that the demand for cassava will increase (Sholihin, 2011). Starch is a carbohydrate obtained easily by extraction and can be produced from various raw materials, such as native starches from maize, wheat, rice, potato, cassava among others. This carbohydrate can be used in various segments of the food and chemical industries in both its native and modified forms (Neelam, Vijay, \& Lalit, 2012).

The authors Mtunguja et al. (2016) and Chipeta et al. (2016) found high starch yields in some cassava cultivars during the 6 (180 days) to 9 month period ( 270 days), but both highlight that the best time for harvest to attain adequate starch levels depends upon the genotype and environment.

The cassava cycle is presented by Alves (2002), they explain that plant emergence occurs within 5 to 15 days, leaves and roots develop from 15 to 90 days and in 90 to 180 days stems are established and the formation of leaves is finalized. From this moment carbohydrate transportation is initiated, this allows the carbohydrates to be stored in the roots from 180 to 300 days then between 300 to 360 days the plant goes into dormancy.

Cassava can be planted throughout the year, however, according to Santisopasri (2001), available water is needed for its development, this is because hydric stress at the beginning of the plant's development stage can cause it to go into dormancy, slowing growth. Mtunguja et al. (2016), explain that when cassava plants are subjected to water stress their hydrocyanic acid levels increase, and therefore must be subjected to industrial processes to eliminate this toxin.

In Thailand, Vietnam and Colombia, according Tran et al. (2015), the starch producers are currently focusing on increasing the process yield, food safety, product quality and economic performance. 
The starch quality, according to Santisopasri et al. (2001), is related to rainfall sufficiency, which ultimately influences soil temperature, nutrient availability, air humidity and even the luminous intensity. Moisture shortages caused by the lack of rainfall, mostly in the first few months of a plants development, have been shown to be sufficient to reduce productivity and starch quality.

Sholihin (2011), found that the starch yields of cassava varieties are heavily influenced by environmental factors, with the yields being directly related to low subsoil density, high relative humidity 4 months after planting and high $\mathrm{pH}$ in the upper layer of soil, it is therefore important to identify such conditions to increase the quality and industrial yield of the roots.

Sagrilo et al. (2006) reported that the harvest period influences cassava quality, they explained that the best season in which to harvest coincides with the physiological dormancy of the plant, because of the high increase in production of tuberous roots and dry matter. A delay in harvest results in the reduction of dry matter content, due to the mobilization of carbohydrates to support the new organs.

In Brazil the cassava dormancy period is during the winter. In view of this, and the other factors described previously that can affect the quality of cassava roots and their starch content, this study aims to monitor starch levels of cassava delivered to a starch producer by farmers, with the aim of verifying the variations in starch level through the course of a year and the seasonality of the deliveries of the product, by using three-years of data taken from a starch producer. At the end of the study, a proposal to minimize the encountered problems is presented.

\section{Methods}

The studied starch producer is located in the west of the State of Paraná, Brazil. The company produces starch processed from cassava roots received throughout the year from Parana and other producing regions. The starch producer, on some occasions, is not supplied with raw materials, during these periods the company is inactive. Thus in this study, the maximum operation period in the same year was approximately 10 months.

Initially, the percentage that each month of production represented of the total production was calculated to give a general evaluation. Following this, the quality of the raw material was identified based on the analyses conducted by the starch producer. At the time of receiving, the company makes an individual assessment of each batch, this assessment is made using a hydrostatic balance, to achieve the final value two samples of $5 \mathrm{Kg}$ are taken. This weight of raw material is subjected to evaluation by the equipment, which provides the result in terms of $\mathrm{g}$ of starch per Kg of product.

According to CEPEA, DEAS, ESALQ, and USP (2016a, 2016b), desirable starch levels in cassava roots should be between 550 and $600 \mathrm{~g}$, or on average be approximately $575 \mathrm{~g}$ when sampling is conducted on $5 \mathrm{Kg}$ of roots. When the value is below the mean content it is common for the agro-industry to impose discounts, as well as bonuses when the content is higher.

The average data for cassava root quality from the monitoring of received batches was collected directly from the starch producer's database. The data was then transferred to Microsoft ${ }^{\mathbb{B}}$ Excel spreadsheets, where, by means of calculations, the percentages of monthly average starch content over the three years were obtained.

The studied starch producer makes use of samples weighing $5 \mathrm{Kg}$, therefore, it was necessary to transform the results so that they related to $3 \mathrm{Kg}$ samples, which are more commonly used in the agro-industry. These transformed results were subsequently applied to the formulas described by Grossman and Freitas (1950), and cited by Oliveira (2011) (see Equations 1 and 2), to estimate the dry matter (DM) and starch content (TA).

$$
\begin{gathered}
M S=15.75+0.0564 \times M_{\text {water }} \\
T F=M S-4.65
\end{gathered}
$$

Where, $M S$ is the percentage of root dry matter, $M_{\text {water }}$ is the weight in water of $3 \mathrm{Kg}$ of cassava, and $T F$ is the percentage of starch content present in the product.

Therefore, the content for which discounts would not be imposed on the farmers, in accordance to the CEPEA, DEAS, ESALQ, and USP (2016a) rules, for weighing and evaluating samples of $5 \mathrm{Kg}$ would be $575 \mathrm{~g}$. This can be subsequently, recalculated to represent a $3 \mathrm{Kg}$ sample, the value $575 \mathrm{~g}$ would result in $575 \times 3 / 5=345 \mathrm{~g}$. Then, by applying these values to Equations 1 and 2 the $M S$ and $T F$ would be 35.208 and 30.558, respectively.

The mean starch content values, obtained for each of the months, comprised a completely random design with three replications (years). The data were compared using an analysis of variance (ANOVA) and a post hoc Tukey test, at $5 \%$ probability $(\mathrm{p}<0.05)$, were conducted using the Assistat 7.6 beta software. Where there was no data present for only one of the years, it was analyzed without the missing data point, however, when there was only one datum point available the point was discarded. 
After conducting the quality studies, an evaluation of the price practices of the market was made for the three year period. This was done based on the available mean monthly values provided by the database containing the CEPEA price series (CEPEA, DEAS, ESALQ, \& USP, 2016b). Finally, a simulation of the amounts paid in relation to the starch contents found over the observed years was conducted, with the objective of identifying the price range that occurs over the months of the year and for the observed three year period. This was done using the CEPEA price and calculating the average discounts imposed on the products in accordance with Equations 3 and 4 presented by the CEPEA, DEAS, ESALQ, and USP (2016a) methodology.

$$
P g=\frac{P M_{t}}{575}
$$

Where, $P g=$ Price paid per gram of starch; $P M t=$ Monthly mean price paid per ton for cassava roots $\left(\mathrm{R} \$ \operatorname{ton}^{-1}\right)$; constant $575=$ Mean value of $M_{\text {Water }}$ for $5 \mathrm{Kg}$ of roots, as indicated by CEPEA in $\mathrm{g}$.

$$
V_{\text {ton }}=P g \times M_{\text {water }}
$$

Where, $V_{\text {ton }}=$ Value of a ton of cassava roots $\left(\mathrm{R} \$ \operatorname{ton}^{-1}\right), P g=$ Price paid per gram of $\operatorname{starch}\left(\mathrm{R} \$ \operatorname{ton}^{-1} \mathrm{~g}^{-1}\right) ; M_{\text {water }}$ is the weight, in grams, of $5 \mathrm{Kg}$ of cassava roots in water (g).

Using the Gretl 1.10.1 software, a frequency histogram was constructed containing the two daily mean values, sampling, morning and afternoon, totaling 1175 values recorded in the databases by the starch producer, with a view of carrying out a general assessment that showed the lowest and highest daily starch contents, as well as the frequency of each. Then a calculation was made to illustrate the lowest and highest income that could be obtained by a hypothetical company with a production of 100 ton day ${ }^{-1}$, taking into account the change in the starch contents presented in the samples, using as its base the price closest to that charged during the year 2016, which was $\mathrm{R} \$ 2000.00$ per ton of starch.

\section{Results and Discussion}

It was noted that the supply of cassava roots to the starch producer follows a seasonal pattern, in that there are no deliveries in some months of the year, such as in January and February, where no deliveries were made in any of the three observed years (2013-2015). In the months of November and December deliveries only occurred in 2015, while in October deliveries were made in 2014 and 2015.

The percentage values for starch delivery to the starch producer can be viewed in Figure 1. Some differences in percentages between the same months, of different years, are due to the occurrence of rain, since too much rain in a single month can harm the harvest and reduce the final amount processed in that month.

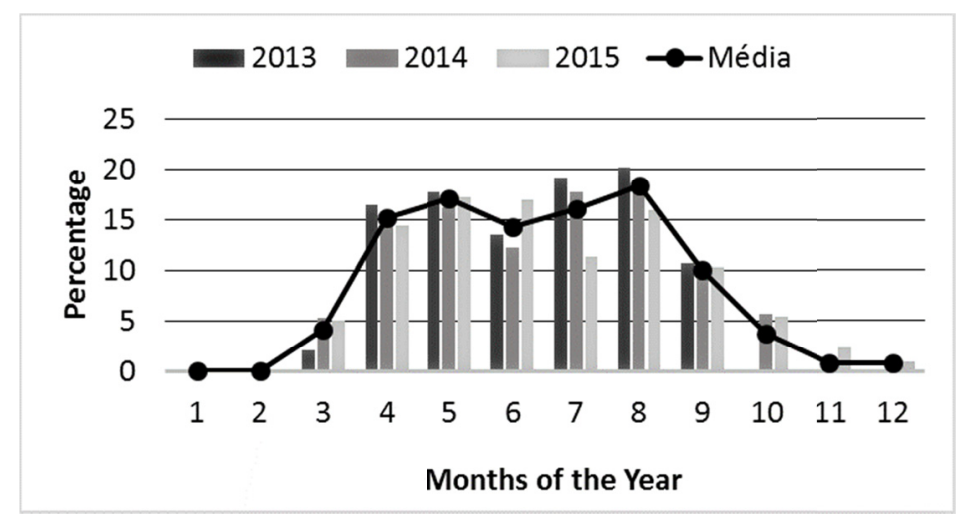

Figure 1. Percentage of cassava roots delivered to the starch producer over the three observed years from 2013 to 2015

It was noted that the highest concentration of product delivery occurred between April and August, which ultimately lead to queues and overloading in the reception sector of the starch producer. This occurred due to the accumulation of starch in the roots during this period, caused by the dormancy brought on by the cooler and drier period, as described by Sagrilo et al. (2006).

Sagrilo (2001), through the study of cassava varieties planted in the northwest of the Paraná State, observed that a reduction in starch contents between the months of November and December was evident. According to the author, this was due to the vegetative growth and regrowth of plants during this period, which results in the consumption 
of the roots starch reserves. The author goes on to explain that after the formation of the leaves, the plant will start to accumulate starch again and that by the end of the second year, after two cycles, the plants will have greater levels of accumulated starch than the plants at the end of the first cycle, a year after planting.

It was found, through the variance analysis and the Tukey test, that there were no statistically significant differences observed at the $5 \%$ probability level between the starch contents found in samples collected by starch producer studied over the years 2013 to 2015 (Table 1).

The average percentages of starch by month, found in the present work, were close to those observed by other authors. Mtunguja et al. (2016) found that starch content in cassava roots was between $23.05 \%$ and $30.74 \%$, however, it is worth mentioning that these values were obtained by laboratory tests. Barbosa et al. (2007), found values between $22.96 \%$ and $31.44 \%$, but they used the hydrostatic balance method, the same as was applied in this study.

Table 1 . The mean monthly starch contents of cassava, obtained via the hydrostatic balance method, received as a raw material by the starch producer. The weighted means were obtained from sampling conducted over 3 years of production.

\begin{tabular}{ll}
\hline Month of the year & $\begin{array}{l}\text { Weighted means of the starch content (3 years) } \\
\pm \text { standard deviation }\end{array}$ \\
\hline March & $29.69^{\mathrm{a}} \pm 0.83$ \\
April & $30.07^{\mathrm{a}} \pm 0.72$ \\
May & $30.42^{\mathrm{a}} \pm 0.80$ \\
June & $30.73^{\mathrm{a}} \pm 0.29$ \\
July & $30.64^{\mathrm{a}} \pm 0.50$ \\
August & $29.92^{\mathrm{a}} \pm 0.35$ \\
September & $29.61^{\mathrm{a}} \pm 0.13$ \\
October & $29.33^{\mathrm{a}} \pm 0.01$ \\
\hline
\end{tabular}

The calculated coefficient of variation values were low, all less than $1 \%$ starch, nevertheless they are capable of causing variability in the industrial production process. This is because even small changes to the starch content of the raw material can reduce the industrial yield; it can be observed that the processing of products with high or low levels of starch presents the same costs.

It was noted that during the middle of the year there was an increase in the starch content of the roots (Figure 2), but this also varied according to the year studied and the farmers evaluated, which could have been the reason for the absence of a statistical difference between the months compared.

The product received in 2014 presented lower starch contents in several months when compared to the other years, this may be related to the cassava price that was above normal levels, especially in the early part of that year (Figure 3). This could have encouraged farmers to advance the harvest of the product at the expense of the quality, even though the raw material had a low starch content resulting in the sum paid to the farmers being subjected to discounts.

The authors Lima, A. L. Ferreira, and M. A. Ferreira (2012) explained that the main bottleneck in the cassava production chain is the variation in the availability of cassava root and its interference in industrial production and farmer profitability. To solve this problem a partnership between starch producers and farmers was created, in order to ensure farmer profitability and the regularity of delivery to the starch producer. The authors explain that the farmers can harvest the cassava after one or two cycles and that the cassava delivered at the beginning of the year is usually harvested after two cycles, while from May to the end of the year the cassava is generally harvested after one cycle.

In the middle of the year, the price of cassava roots generally decreases, while the starch content increases, this is due to the law of supply and demand, as many farmers harvest and sell their product at this time of year, therefore, the greater quantity of product reduces the price (Figure 3 ). 


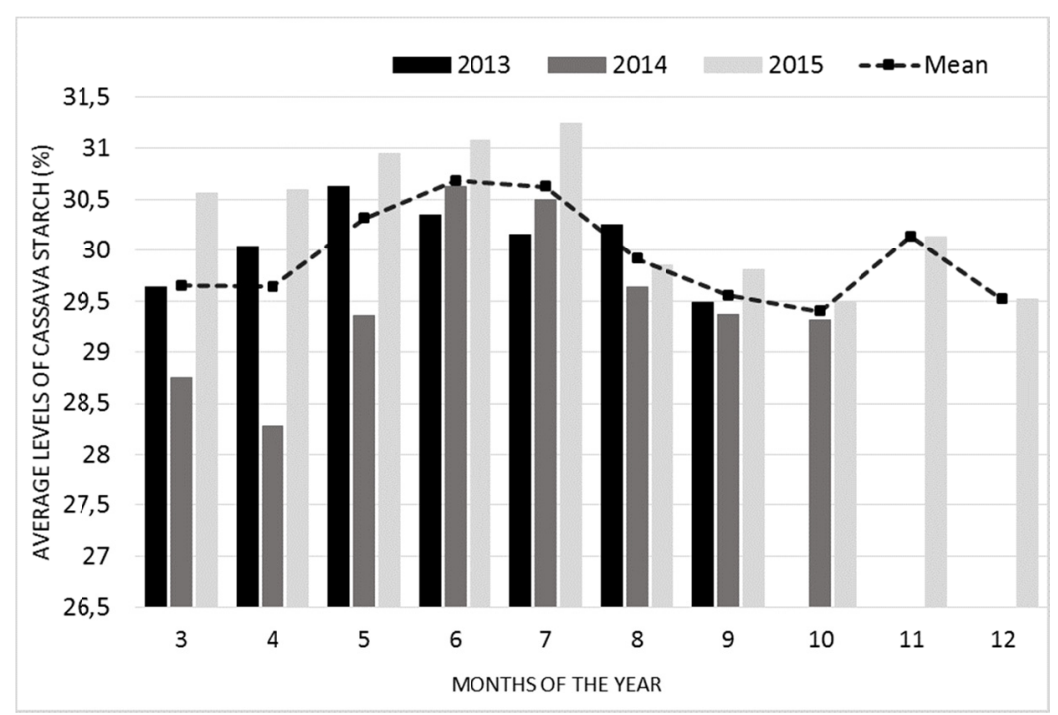

Figure 2. The average starch content present in the cassava roots throughout the observed years

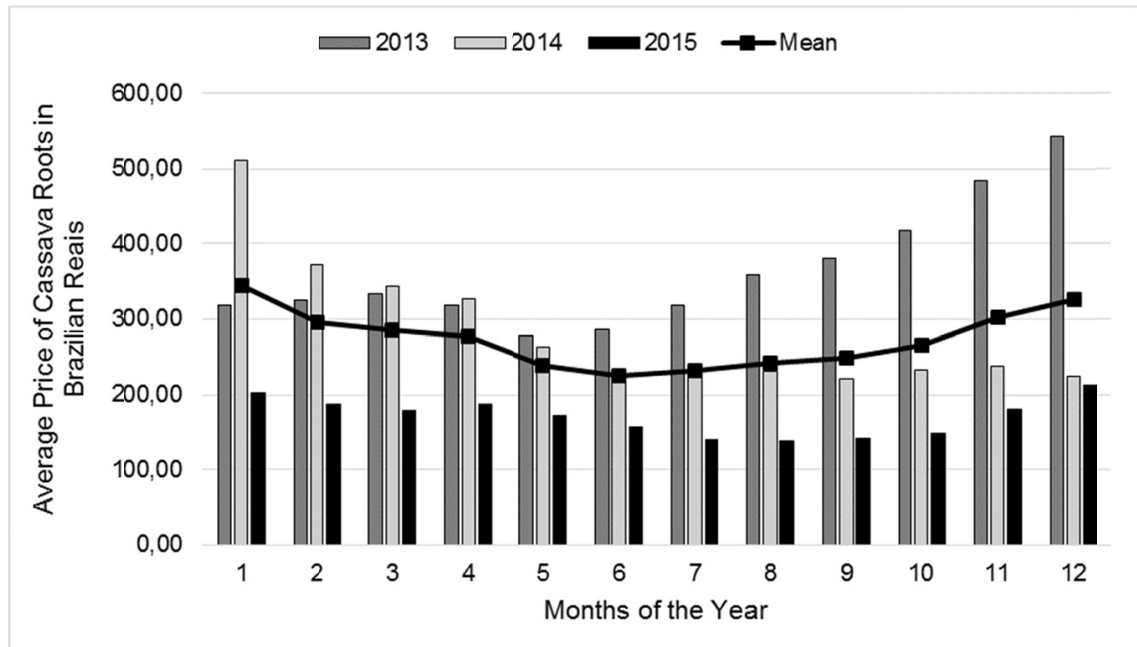

Figure 3. Average price in Brazilian Reais (R\$) of cassava in western Paraná, provided by CEPEA, DEAS, ESALQ, and USP (2016b)

However, by calculating it based on starch contents, by means of the discounts and bonuses described in the CEPEA, DEAS, ESALQ, and USP (2016a) methodology, it was observed that during the inter-harvest period farmers received prices lower than the market average. It was only in the months of June and July, during the harvest, that farmers received, on average, close to the market value. It is of note that some farmers were able to obtain higher than the average market value, which can be observed in the maximum price columns of Figure 4, regardless of the time of year. 


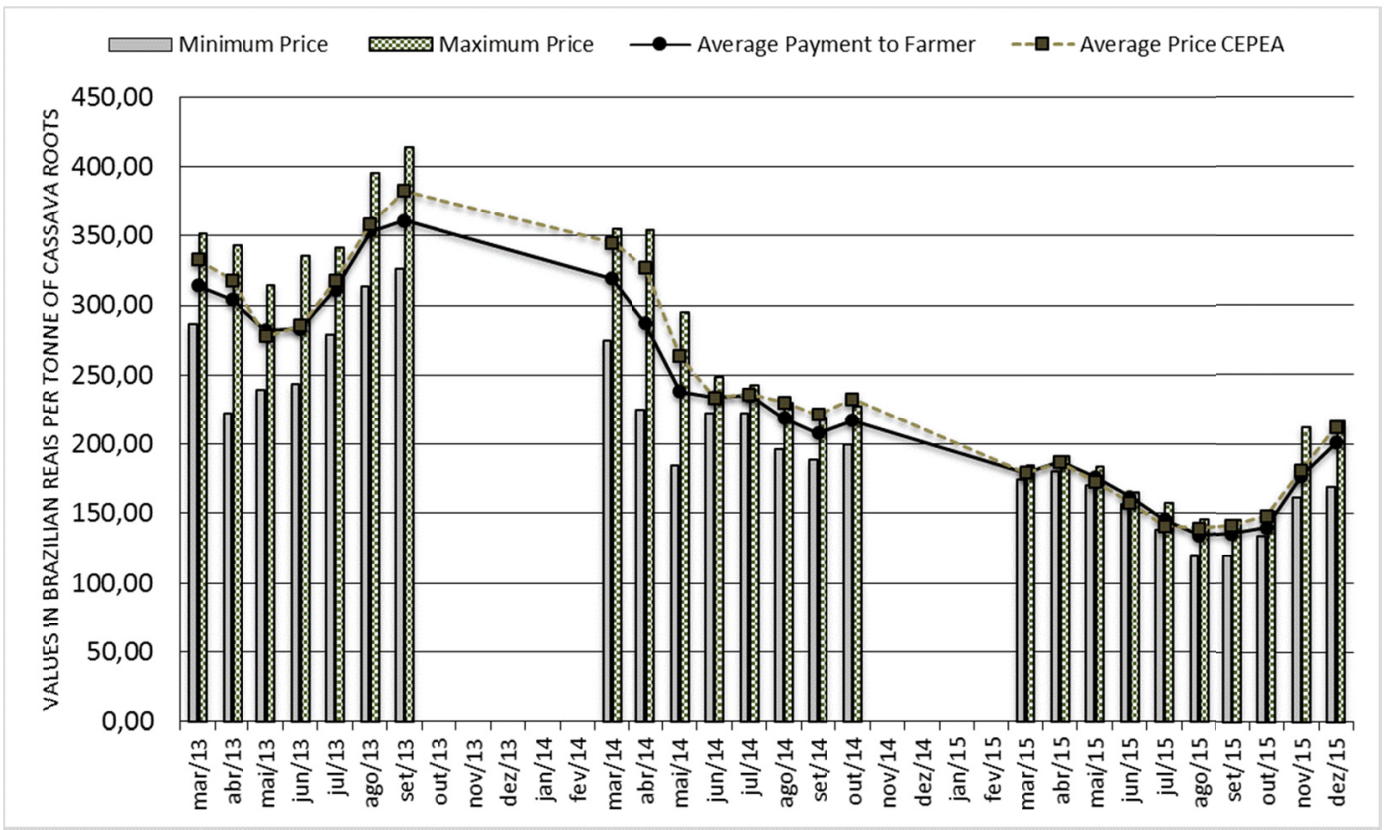

Figure 4. Minimum and maximum average prices received by farmers for the delivery of their product at different times throughout the three observed years, compared to the average monthly values provided by the CEPEA

In Figure 5 a histogram is presented that describes the starch content over the processing days of the starch producer for the three studied years (2013-2015). It was possible to verify that on a few days the average attained values were close to $24 \%$ starch, while on other days the attained starch content was very high, around $34 \%$. This leads to the conclusion that throughout the production process performed by this company, there was an average of a 10 percentage point variation in starch contents of the received raw materials during nine months of the year (March to November).

The overall average was $29.991 \%$ with a standard deviation of 1.2254 , the data was not normally distributed, confirmed by the Doornik-Hansen, Lilliefors, Shapiro-Wilk and Jarque-Bera tests, all of which presented a p value close to zero, a histogram was constructed with 11 classes to visualize the variability (Figure 5).

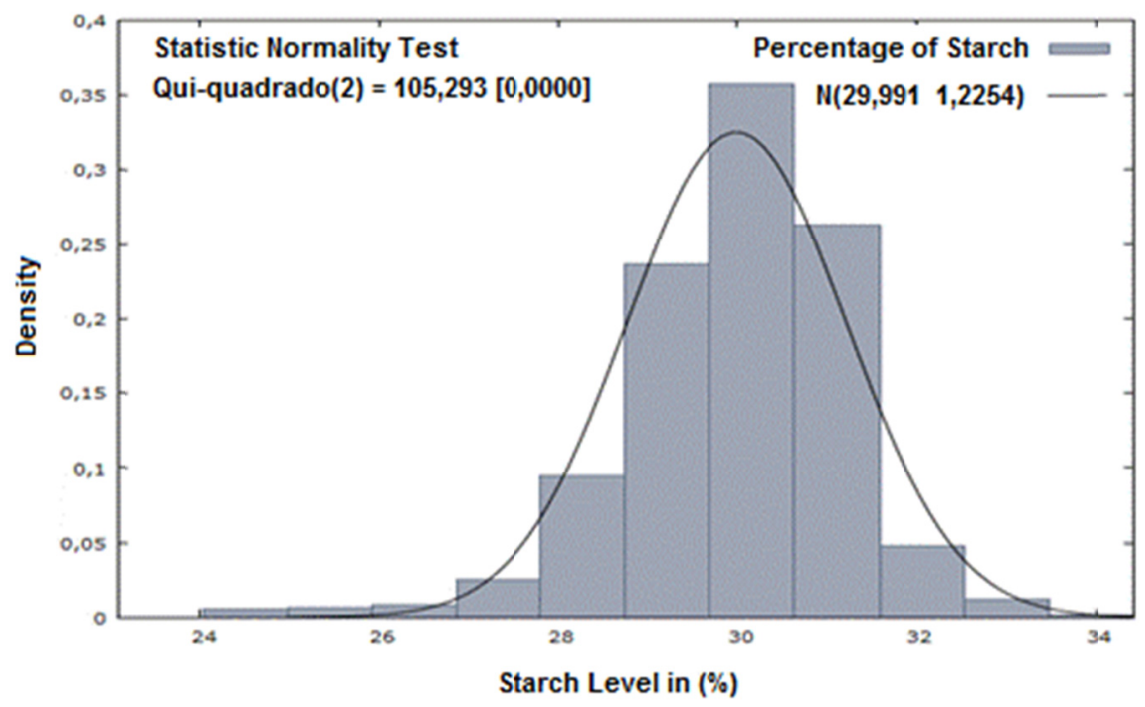

Figure 5. Frequency histogram illustrating the starch percentage levels obtained by applying Equations 1 and 2 to the average of the two daily measurements obtained by hydrostatic balance weighing, transformed to $3 \mathrm{~kg}$, during the operations of a starch producer over the three studied years (2013-2015) 
The highest frequency was found for the $30 \%$ starch content; this value is very close to the average value proposed by CEPEA for receiving without discounts. However, all values below this had discounts applied to the payment, because they did not achieve the minimum targets proposed by the CEPEA, DEAS, ESALQ, and USP (2016a) rules adopted by many agribusinesses.

Many factors can alter the levels of starch reserve in cassava roots, such as genetic, soil and climate related factors; in addition to those imposed by the plants own cycle. Santisopasri (2001), Adams (2002), Sagrilo et al. (2006), and Sholihin (2011) explain that it is not possible for the cassava producers to stabilize the starch content throughout the year, on account of these limitations.

On the other hand, it is too complicated for a starch producer to work during months where the mean percentages of starch are very low. Suppose that within the production process no loss occurs of any kind, however, it is important to make clear that losses do occur and are around 3\% of starch in the raw material. The example given in the following paragraph was based on the average price from March to September of 2016 and is intended to demonstrate what would be the differences found by the starch industry when working with different qualities of raw materials.

Suppose a hypothetical starch producer has an average production capacity of 100 ton day $^{-1}$, with an average yield of $30 \%$ (the most frequent value in the frequency histogram), with an input of 334 ton day ${ }^{-1}$ of cassava roots. With this data, you can calculate income for raw materials, with between $24 \%$ and $34 \%$ starch, assuming a daily starch production of 80.16 ton day $^{-1}$ and 113.56 ton day ${ }^{-1}$ respectively, resulting in a difference between the two starch levels of 33.4 ton day ${ }^{-1}$. Given that the market starch price per ton is close to $\mathrm{R} \$ 2,000.00$, the monetary difference in one day of production between a day with high quality and low quality raw material would be $\mathrm{R} \$ 66,800.00$.

To simplify these calculations, a specific integer value for starch percentage that could be accepted as borderline for a product with higher quality was established. Noting that the CEPEA, DEAS, ESALQ, and USP (2016a) evaluation refers to a desirable range and that $30.558 \%$ was the average, not all companies adopt these same classification limits. In this work the average was rounded to $30 \%$, such rounding was performed for didactic reasons, to simplify the understanding of the discussion and the reason for selecting this percentage was because it was the most frequent value in the histogram (Figure 5).

Thus, it is worth mentioning that on average, over the period studied, the percentage of farmers who delivered products with superior quality (over $30 \%$ starch) were higher and the percentage that delivered products with an inferior starch content, less than $30 \%$, were few, as can be seen in Figure 6. It can also be seen that products lower than $30 \%$ starch were greatly reduced in the middle of the year. This confirms the seasonality of the product and the ease of obtaining high quality raw material between June and August, which leads farmers to concentrate their crops in those months.

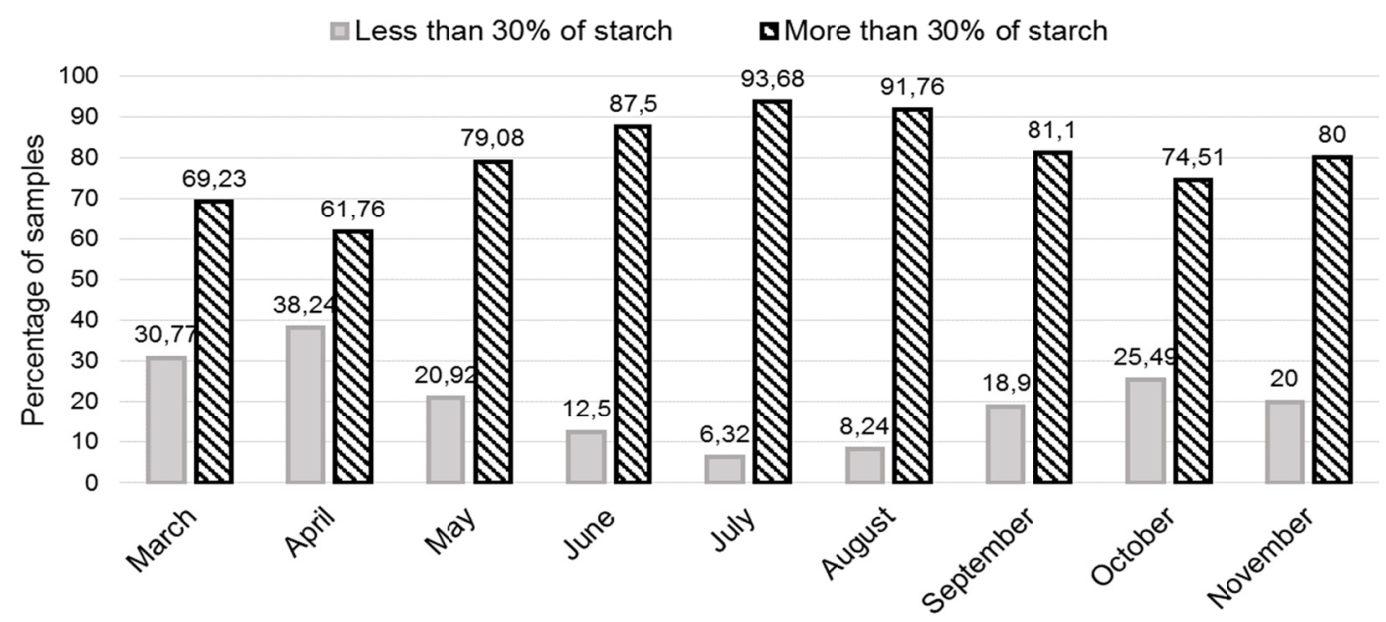

Figure 6. Comparison chart of starch content percentages, which show contents inferior and superior to $30 \%$ starch in cassava roots of sampled producers, throughout the years 2013 until 2015 
In view of the presented difficulties of the starch producers and farmers, imposed by planting limitations arising from climatic, soil and genetic factors, and the findings of this study, a methodology for quality evaluation that is slightly different from the one currently adopted is suggested. The current methodology only takes into account the $M_{\text {water }}$ mean values for $5 \mathrm{Kg}$ of roots, $575 \mathrm{~g}$, as indicated by CEPEA, DEAS, ESALQ, and USP (2016a), for calculating discounts and bonuses.

After the completion of this study, it is believed that the adoption of the inferior and superior limits should also be taken into account. This study suggests that if an upper limit was applied in the middle of the year (June, July and August), when it would be possible for farmers to achieve higher starch contents, this would result in the worst quality crops, representing on average $10 \%$ of the raw materials received by the starch producer, not being harvested at this time. This would reduce the peak of delivery and the queue of trucks that arrive at the starch producer during those months and increase the delivery at other times when the requirements would be less.

In summary, the average of $575 \mathrm{~g}$ of $M_{\text {water }}(30.5 \%$ of starch) would no longer be adopted for the whole year, instead $550 \mathrm{~g}$ of $M_{\text {water }}(29.71 \%$ of starch) would be used for the months of March, April, August, September, October, November and December, while $600 \mathrm{~g}$ of $M_{\text {water }}(31.4 \%$ of starch) would be used for the months of May, June and July, or another limit judged to be adequate. This action would have a dual purpose, reduce the exaggerated flow of deliveries during harvest and expand the interest of the farmer for deliveries made outside of this time, since in addition to the requirement for deliveries to be generally less often the price is also higher.

The methodology proposed to the starch producers would be relatively simple to adopt. It would be more demanding during the harvest months, requiring a higher quality from the farmer, so they would not be subjected to discounts. In the months where there is greater difficulty in obtaining quality raw materials, the industry patterns are more benevolent, incentivizing farmers who have the product available to supply it, so that the starch producer does not need to remain idle. All values used in this paper were based on those proposed by CEPEA, DEAS, ESALQ, and USP (2016a), but each organization can adopt a bespoke methodology in accordance with their specific conditions, especially considering that throughout the study many differences between starch contents could be observed for the same months of different years.

\section{Conclusion}

It was concluded that the change in cassava starch contents occurred due to many factors, which are difficult for the farmer to control and that delivery concentrated in the middle months of the year generates disruption to the agro-industry.

The cassava starch contents obtained from the roots showed large differences, despite the monthly averages not presenting statistically significant differences, in that daily starch values ranged from $24 \%$ to $34 \%$. The calculations made for days worked with roots containing these different values, resulted in a high monetary difference, which causes a major management problem for the starch producer.

In this context and with the evaluation of the prices received by the farmers throughout the three studied years, we believe that these changes in payment methodology would provide a good deal. Calculating based on the product classification by the mass in water, which is correlated to starch contents by models, could be more demanding in times that are more favorable and the targets could be less demanding at times when the industry is traditionally idle due to lack of raw materials. This would be used instead of performing discount and bonus calculations based solely on one value for the whole year.

With this small modification we believe that the framers would better distribute the harvest throughout the year, since there would be a motivation for them to make cassava root deliveries out-of-season and there would be a reduction in harvesting excess during the season when the product increases in quality.

\section{References}

Alves, A. A. C. (2002). Cassava Botany and Physiology (Chapter 5). In R. J. Hillocks, J. M. Thresh, \& A. C. Bellotti (Eds.), Cassava: Biology, Production and Utilization. New York: Cabi Publishing. Retrieved January 10, 2016, from http://ciat-library.ciat.cgiar.org/articulos_ciat/cabi_08ch5.pdf

Barbosa, C. Z. R., et al. (2007). Caracterização de dez Clones de Mandioca Cultivados no Estado de Roraima. Agro@mbiente On-Line, 1(1),24-27. https://doi.org/10.18227/1982-8470ragro.v1i1.141

CEPEA (Centro de Estudos Avançados em Economia Aplicada), DEAS (Departamento de Economia, Administração e Sociologia), ESALQ (Escola Superior de Agricultura "Luiz de Queiroz"), \& USP (Universidade de São Paulo). (2016a). Metodologia: Raiz de Mandioca. Retrieved October 6, 2016, from http://cepea.esalq.usp.br/mandioca/?page $=37$ 
CEPEA (Centro de Estudos Avançados em Economia Aplicada), DEAS (Departamento de Economia, Administração e Sociologia), ESALQ (Escola Superior de Agricultura "Luiz de Queiroz"), \& USP (Universidade de São Paulo). (2016b). Série de preços. Retrieved June 20, 2016, from http://cepea.esalq.usp.br/mandioca/\#

Gretl. (2015). Gnu Regression, Econometrics and Time-series Library (Software Livre: Versão 1.10.1). Retrieved September 2, 2015, from http://gretl.sourceforge.net/pt.html

Lima, E. J. de, Ferreira, A. L., \& Ferreira, M. A. (2012). Sazonalidade da demanda da produção de mandioca e seu impacto na produção industrial. In M. A. Ferreira, A. L. Ferreira, J. L. Dalto, \& R. Oliveira (Eds.), Práticas de gestão de produção e operações (p. 346). Londrina: Universal.

Mtunguja, M. K., Henry, S. L., Edward, K., Joseph, N., \& Yasinta, C. M. (2016). Effect of genotype and genotype by environment interaction on total cyanide content, fresh root, and starch yield in farmer-preferred cassava landraces in Tanzania. Food Science \& Nutrition, 4(6), 791-801. https://doi.org/10.1002/fsn3.345

Neelam, K., Vijay, S., \& Lalit, S. (2012). Various Techniques for the modificatins of Sarch and the Aplicationa of its Derivatives. International Research Journal of Pharmacy, 3(5), 25-31.

Oliveira, N. T., et al. (2011). Caracterização e identificação de clones de mandioca produzidos em Roraima para o consumo in natura. Revista Agro@mbiente On-line, 5(3), 188-193. https://doi.org/10.18227/1982-8470ragro. v5i3.624

Rosenthal, D. M., Rebecca, A. S., Rebecca, E. M., Aleel, K. G., Timothy, R. C., Claude, M. F., ... Donald, R. O. (2012). Cassava about-FACE: Greater than expected yield stimulation of cassava (Manihot esculenta) by future $\mathrm{CO}_{2}$ levels. Global Change Biology, 18, 2661-2675. https://doi.org/10.1111/j.1365-2486.2012. 02726.X

Sagrilo, E. (2001). Produtividade de três cultivares de mandioca (Manihot esculenta, Cratz) em diferentes épocas de colheita no segundo ciclo vegetativo (p. 136, Dissertação. Mestrado em Agronomia da Universidade Estadual de Maringá).

Sagrilo, E., Pedro, S. V. F., Manoel, G. P., Maria, C. G. V., Carlos, A. S., Marcus, V. K., ... Fabrício, R. (2006). Effect of harvest period on foliage production and dry matter distribution in five cassava cultivars during the second plant cycle. Brazilian Archives of Biology and Technology, Curitiba, 49(6), 1007-1018. https://doi.org/10.1590/S1516-89132006000700019

Santisopasri, V., Kanjana, K., Sunee, C., Kuakoon, P., Klanarong, S., \& Christopher, G. O. (2001). Impact of water stress on yield and quality of cassava starch. Industrial Crops and Products, 13(2), 115-129. https://doi.org/10.1016/S0926-6690(00)00058-3

Sholihin. (2011). AMMI Model for Interpreting Clone-Environment Interaction in Starch Yield of Cassava. HAYATI Journal of Biosciences, 18(1), 21-26. https://doi.org/10.4308/hjb.18.1.21

Tran, T., Guillaume, D., Martin, A. M.-S., Gustavo, A. V.-H., Andres, G.-T., Kuakoon, P., ... Dminique, D. (2015). A comparison of energy use, water use and carbon footprint of cassava starch production in Thailand, Vietnam and Colombia. Resources, Conservation and Recycling, 100, 31-40. https://doi.org/10.1016/ j.resconrec.2015.04.007

\section{Copyrights}

Copyright for this article is retained by the author(s), with first publication rights granted to the journal.

This is an open-access article distributed under the terms and conditions of the Creative Commons Attribution license (http://creativecommons.org/licenses/by/4.0/). 